\title{
Aspects of Navigation Development in the Region of Shkodra during XVIII Century and the Beginning of XIX Century
}

\author{
Prof. Dr. Adrian Papajani \\ Faculty of Social Education, Department of Social Sciencies, University "Aleksandër Xhuvani", Elbasan, Albania \\ adripapajani@yahoo.com
}

Doi:10.5901/mjss.2015.v6n1s1p156

\begin{abstract}
Navigation, as a special type of transport has played a crucial role in the economic development of Shkodra region. Its great importance in this regard was mainly determined by two factors: The very favorable geographical position of the city of Shkodra in relation to the territorial extent of the surrounding region. Proximity to the lake with the same name and the Buna River in a navigable perennial character defined it as a transit port in the circulation of goods. Ulcinj, a town very near Shkodra, inherited a very rich tradition in the field of sailing and what was more important, it possessed a powerful merchant fleet capable of sailing not only in the Adriatic Sea, which for Ulcinj inhabitants constituted the so-called courtyard of the house1, but up to the Mediterranean and Aegean seas, visiting Istanbul, Cairo, Izmir, Alexandria etc.
\end{abstract}

Keywords: sailboat, Ulcinj merchant fleet, Venetian merchant fleet, steamer,

\section{Means of Sailing (Sailboats)}

During the eighteenth century there was a comprehensive strengthening of Ulcinj merchant fleet. It increased mainly through the construction of new vessels of various tonnages. For this purpose near the town jetty it was located the construction site (shipyard) where as raw material was used lumber from the rich forests around the town.

During the first 6 months of the year 1711 in the shipyard were built 12 different sailboats of various tonnages. ${ }^{2}$ By a notice of Durres Venetian consul, Peter Rosa, sent in June 1707 to the Venetian Senate it was learned that Ulcinj and Durres fleet consisted of 250 sailboats of different sizes, whereas two years later, this number had reached 300 maritime vessels while their crew arrived in $4000-5000$ people. $^{3}$

This continuous strengthening of the Ulcinj fleet, which would proceed even in the nineteenth century, made it possible that the latter rank the second, after the Venetian merchant fleet, leaving behind that of Ragusa.

This fact aroused a permanent and growing concern of Venice which began to use different ways to curb the further strengthening of the Ulcinj fleet.

There are not missing for this purpose various reports made by his consuls and vice / consuls in Durres and Shkodra where were recommended various ways to eliminate the competition of Ulqin citizens.

In 1706, it is recommended the delivery in Shkodra not of large vessels which can not go in Shkodra because of their inability to navigate through Buna but of smaller vessels which can enter up to the town jetty. Only in this way the movement of goods of the merchants of Shkodra would be conducted by Venetian ships rather than by those of Ulcinj ${ }^{4}$.

A year later the Venetian consul in Durres, Peter Rosa, in a report sent to the center stated that in his opinion the only way to successfully overcome the threat of Ulcinj fleet was a direct transfer of goods from Durres to Venice and not through Castelnuovo and Ragusa ${ }^{5}$. While in 1747 it is learned that, in order to prevent the transportation of goods to Venice with Ulcinj vessels when the Venetian vessels were missing, the Venetian vice consul in Shkodra Anton Duoda practiced the system of leasing contracts ${ }^{6}$

${ }_{1}^{1}$ R. Zojsi. "An ethnographic overview on navigation traditions in Albania. Journal of Social Sciences. 1955. No 4, f. 175

2 V. Papahagi. "Aromani moscopoleni si comertul venetian in sec. al XVII-lea si al XVIII- lea. Bucuresti, 1935, f. 187

${ }^{3}$ Z. Shkodra. "The problem of the Albanian market in the XVIII century. Historical Studies. 1966. No 3, f. 69.

Note 36 and 37 issued by Archivio di Stato di Venezia. Lettere, consoli Durazzo dt.30. 06. 1707 dhe 21. 11. 1709.

4 S. Naci. "About Sanjak of Shkodra trade with the Republic of Venice during the XVIII century. Bulletin of the State University of Tirana, social sciences series. 1963 No 1, p. 17, note 47.

5 Ibid, p. 19

${ }^{6} \mathrm{Ibid}$, p. 30 , note 70 
Despite countless efforts of Venetians and Ragousians to damage the Ulcinj merchant fleet, the latter increased and increasingly strengthened.

Such a phenomenon should be seen closely related to the rapid economic development of Shkodra region, increasing and strengthening of the financial capital of Shkodra merchants as a result of this development which led to higher investments made by the latter in the Ulcinj merchant fleet but even in individual investments. Consequently, in 1818, this fleet consisted of 400 vessels units ${ }^{7}$.

In 1838 the ratio between the absolute number of the population of Ulcinj and large navigating vessels was 17 persons per unit, whereas in 1857 this ratio is about 20 persons per vesse ${ }^{8}$

\section{Navigation Motor Vehicles}

The first half of the nineteenth century marks a further increase in maritime transport in the region of Shkodra. After the final departure of Venice from the political and merchant scene in 1797 it began to increasingly grow the Austrian influence. A powerful tool in this regard was the Austrian transport company with LLOYD steamer. Since 1820 this transport company was a postal courier between the Austrian consulate in Shkodra and the post office of Kotor; initially twice a month, once a week in 1840 and since January 1843 twice a week. ${ }^{9}$

In 1853 it established the second Dalmatian line or the so-called Dalmato-Albanian which provided the link between Trieste with Dalmatian coast of Shkodra, while in 1861 it is established Trieste-Durres line which again communicated with Shkodra ${ }^{10}$

Now the bulk of the circulation of goods of Shkodra traders was oriented from Austria while its political and economic influence on the region of Shkodra was continually strengthened. In their beginnings these cruise lines were designed primarily for passengers and mail transport. This is evidenced by the facts that in drafting the schedules were set out frequent stops but with short time stay, what did that the transported goods were discharged in the pier but often it was no time to charge the new goods. ${ }^{11}$ In those cases when the latter could be charged, delays were causing in the schedule. The consequences of these delays caused to Shkodra merchants who were located in the trading Trieste Piazza, were severe.

On 1202.1855 some traders of this Piazza, the majority from Shkodra, who call themselves Albanian merchants (negozianti Albanesi) send a protest in Trieste Post Directory. The reasons for this protest were related to the fact that starting from 1 January of that year the letters from Trieste to Shkodra arrive one week later than previously. Such a delay made it possible not to combine the simultaneous arrival of the bill of lading, which was sent by post, with the arrival of the goods. Non-accompaniment of goods with the bill of lading made it possible that the LLOYID company should not allow its dismissal until the arrival of the latter. In these cases, the warehouses were taken from other merchants while their goods remained outside. The protest was signed by 21 merchants: Gasper Muzhani, who also was their official representative, Andrea Coba, Gjon Kici, Zef Simoni, Pjeter Gjoka, Marko Sereqi, Simon Sereqi, Pjeter Shiroka, Zef Parruca, Gjergj Selvori, Konstandin Moisi, Gjon Lauda, K. Kolea, K. Veveshka, S. G. Melgushi, M. Beqiri, A Basha, Omer Beqiri, M. Gjimrezi, Hysen Haxhia and Lorenc Kraja ${ }^{12}$

By the end of the first half of the XIX century besides the foreign steamboats also appears the first Albanian steamers. Although initially not quite numerous and with a modest transport capacity they constitute an important indicator of the high level of navigation in the region of Shkodra, a development closely connected with the growth of manufacturing and circulation of goods outside the borders of this region.

In the early XIX century it is bought by the Bianki family a steamer with a capacity of 120T.

By the second half of the same century it is not mentioned anymore ${ }^{13}$

In 1865 merchants, perhaps from rich families like Bianki, Daragjati or Muzhani, bought by the LLOYD Austrian navigation company a steamer of $84 \mathrm{~T}$, which was put into service for a short time in Obot - Trieste line and vice versa ${ }^{14}$

In July of that year Jak Muzhani appears to be the owner of "Scutari" steamer which covered Shkodra - Venice -

\footnotetext{
7 Z. Shkodra. "Albanian town during the Albanian National Renaissance. Tirana 1984, f.274.

${ }^{8}$ R. Zojsi. "An overview ....p. 79, note 97 and 98.

${ }^{9} \mathrm{U}$. del Bianco. "Il Lloyd Austriaco e la marina postale dell'Austria e dell'Ungheria. 1985, p.145 and note 1.

$10 \mathrm{lbid}, \mathrm{p} .34,36$

11 lbid, p. 37

12 Central State Archive. Fund 608, file 11, sheet 1.

${ }^{13}$ R. Zojsi. "An ethnographic overview...p. 189

${ }_{14}$ Z. Shkodra. "Albanian town during the Albanian National Renaissance. Tirana 1984, p.277.
} 
Trieste and the return route. It was also sent the mail 15 with this steamer, besides the transport of goods and passengers.

In 1868, Muzhani family bought a new motorsailer (motor-sailboat) called "Vilayet" which originally covered Trieste - Durres - Vlora and the return route. ${ }^{16}$ The motorsailer with a capacity of $165 \mathrm{t}$ transported goods and citizens divided into three classes $^{17}$.

In the summer of 1870 "Vilayet" covered Malta - Tripoli and the return route. In his first trip in August of that year were traveling 70 passengers among whom also a pasha ${ }^{18}$. In 1868 besides "Scutari" and "Vilayet" steamers, Jak Muzhani also became the owner of a third steamer. It is about a yacht which was much larger than "Scutari" steamer. It had previously been owned by Archduke Maximilian, Emperor of Mexico, and had cost 11,000 fiorint ${ }^{19}$. In order to buy it, Jaku ran in auctions with LLOYD. The yacht was quite comfortable and with an advanced technique for that time. It is contemplated to be drowned near Tripoli in $1880^{20}$.

The years ' 60 - ' 70 of the XIX century mark a further intensification of navigating in Buna. Consequently we have also an increase in competition between domestic vessels with Austrian navigation company LLOYD which enjoyed a versatile support not only from the Austrian government but also from the Turkish government, the latter forced by existing agreements between the two countries.

In this situation, the creation of a joint navigating company by Shkodra merchants was considered by the latter as an effective tool to counter LLOYD. This effort unfolds before us quite clear from a letter that Jak Muzhani in early 1870 wrote to his brother Lorenc, who at that time was also a member of Belediye of Shkodra. In this letter Jaku makes an interesting proposal: ...Adjust with this government (of Shkodra A.P) to combine a company, in order to or by means of a small steamer "Vilayet" to be sent to the Customs (of Shkodra A.P) or inside the "Vilayet" to be performed the control in the Gulf of Buna and hence "Vilayet" will go inside. The company would urge the government a permit for 10 years to avoid the navigation of another company in this region. So we will be the first of this institution to have venture, as have been given to the others for the Danube. I don't know how much will be able the Shkodra sailors and the machinist. For the payment, i.e for the rent let him decide, the pasha. You just try to get the privilege ${ }^{21}$.

Therefore Jak Muzhani, in order to avoid any possible risk from the competition with LLOYD and the Ulcinj sailboats, intends to focus on his hands the monopoly of navigation throughout the water network of Shkodra. Obviously, such a great venture could not be accomplished from him without the assurance of a strong political support, considering the fact that in this case would be affected primarily economic and political of Austria, which was conducting them through LLOYD. Political support will be provided through participation in this company of the Vizier of Shkodra. In return he will be given economic concessions.

In March 1870, Jak Muzhani from Trieste sends to his brother Lorenc in Shkodra a letter where among other things he requires that the latter once again reiterate the request made at the vizier concerning the creation of a common navigating company and if he will not accept to lay down a second request which consisted in giving the privilege to carry out works to deepen the Gorge of Buna by Jaku because ... "otherwise these merchants, though doomed, will continue to charge with boats 22

By deepening the Gorge of Buna he thought to bring "Vilayet" up to Shkodra and thereby compete successfully LLOYID and especially the Ulcinj sailboats. For this he had to establish a dam consisting of 180 beams, whereas as a financial compensation for this enterprise he had projected that he would take a rent of 1 franc per ton for 20 years from each sailboat or steamer that would enter the gorge ${ }^{23}$

This constituted a huge venture and too brave for that period, but almost impossible to accomplish it. There lacked the financial and technical tools without mentioning here the barriers that might come from his opponents.

However efforts to ensure the material basis were not missing. Meanwhile, it is learned that the same month the vizier had taken a positive response to some several offers for the purchase of a small steamer which could sail through Buna as well as the appropriate machinery. The steamer was offered with a price of 1850 sterling while working equipment will be purchased in England ${ }^{24}$.

${ }^{15}$ Central State Archive. Fund 81, folder 77, sheet 38

${ }^{16}$ Central State Archive. Fund 608, file 38, sheet 4.

$17 \mathrm{Ibid}$, file 39 , sheet 20.

18 Ibid, file 47, sheet 1 .

${ }^{19}$ Central State Archive. Fund 81, folder 80, sheet 154.

${ }^{20}$ R. Zojsi. "An overview... p. 41. Idem, p. 189

${ }^{21}$ Central State Archive. Fund 608, file 45, sheet 13

${ }_{22}$ Central State Archive. Fund 608, file 45, sheet 29.

${ }^{23}$ Central State Archive. Fund 81, folder 89, sheet 458.

$24 \mathrm{Ibid}$, sheet 42 
By a letter dated 06.25 .1870 between brothers Muzhani it is confirmed the fact that Turkish government authorities in Shkodra had decided to give the privilege of Buna deepening to Jak Muzhani, however hereinafter this venture is not mentioned anymore. Apparently Jak Muzhani withdrew, probably for financial reasons.

Such an attempt made by Jak Muzhani did not remain alone. Similar efforts were also made by other merchants of Shkodra with the sole intention: the establishment of a joint navigation company of Albanian character.

Such a finding, as far as we know, previously unknown, is evidenced by a letter dated 3.05.1870 that Engjell Coba from Shkodra sends to Stefan Bianki in Venice, in which among other things he says that ..." Here in Shkodra it is supposed to be done LLOYD Scutarino and they want to do this with stocks. The day before yesterday merchants gathered in the warehouse of Koxhabashi and decided that everyone purchase shares amounting to 25 gold Napoleons to calculate how much gold Napoleons would be collected. All shareholders began to enroll. The first houses of 10 stocks, i.e.: Selim Gjyrezi, Oso Mani, Isuf Muca, Pietro Shiroka, Nikollë Shiroka, Kovaci, brothers Muzhani, Gjon Kapiteni and others 10 stocks. I was also called to be asked (Engjell Coba, A.P.). I told that I don't have the same opinion as the uncle (Stefan Bianki, A.P.) but should not be separated from friends and we wrote 10 stocks, but nothing is set. Up to now it is supposed to be done 180 stocks from 25 Napoleons, and still is too much without being put. All this was done to see if money would be collected or not and it seems that it happens (it is collected)...25.

About 3 days later, from the same correspondence sent from Shkodra we are informed that ... "the stocks of the steamers have remained at half way and are not mentioned by anyone anymore and I don't know what about, but as it is wont to us there are only words and no deeds, or no work 26

These significant data reflect the efforts of merchants of Shkodra for the establishment of a joint navigation company similar to that of LLOYD. The goal was clear. They wanted to face foreign competition being organized in the example of other similar foreign companies as well as to reduce the losses they were suffering, but their attempt was not successful. Reasons should have been different; however one of the most determined opponents of this idea must have been the LLOYD Austrian navigation company for which the establishment of an Albanian navigating company risked of the navigation monopoly and the privileges that it had secured on this occasion.

Such efforts of Shkodra commercial bourgeoisie constitute an important indication of increasingly strengthening of its economic positions.

Another similar attempt with the same goal is made again by the representatives of this bourgeoisie in 1878. The project was designed by Zef Jubani and it was similar to those of LLOYD and the Italian navigation company "Puglia" which was established two years ago. But also this time, this attempt has not been crowned with success. The main cause of its failure was the intervention near the Turkish government and Austria-Hungary 27).

\section{References}

R. Zojsi. "An ethnographic overview on navigation traditions in Albania. Journal of Social Sciences. 1955. No 4, f. 175

V. Papahagi. "Aromani moscopoleni si comertul venetian in sec. al XVII-lea si al XVIII- lea. Bucuresti, 1935, f. 187

Z. Shkodra. "The problem of the Albanian market in the XVIII century. Historical Studies. 1966. No 3, f. 69 . Note 36 and 37 issued by Archivio di Stato di Venezia. Lettere, consoli Durazzo dt.30. 06. 1707 dhe 21. 11. 1709.

S. Naci. "About Sanjak of Shkodra trade with the Republic of Venice during the XVIII century. Bulletin of the State University of Tirana, social sciences series. 1963 No 1, p. 17, note 47.

Z. Shkodra. "Albanian town during the Albanian National Renaissance. Tirana 1984, f.274.

U. del Bianco. "Il Lloyd Austriaco e la marina postale dell'Austria e dell'Ungheria. 1985, p.145 and note 1.

Central State Archive. Fund 608, file 11, sheet 1.

Central State Archive. Fund 81, folder 77, sheet 38

Central State Archive. Fund 608, file 38, sheet 4.

Central State Archive. Fund 81, folder 80, sheet 154.

Central State Archive. Fund 608, file 45, sheet 13

Central State Archive. Fund 608, file 45, sheet 29.

Central State Archive. Fund 81, folder 89, sheet 458.

\footnotetext{
$25 \mathrm{lbid}$, sheet 460

$26 \mathrm{Ibid}$, sheet 463

27 Ibid, sheet 463
} 